\title{
Rancang Bangun Sistem Hotspot Portable dengan OpenWRT
}

\section{Engineering of Portable Hotspot System using OpenWRT}

\author{
L. Budi Handoko ${ }^{1}$, Oki Setiono ${ }^{2}$ \\ 1,2 Teknik Informatika, Fakultas Ilmu Komputer, Universitas Dian Nuswantoro \\ Jl. Nakula 5 - 11, Semarang 50131, 024-3517261 \\ handoko@dosen.dinus.ac.id ${ }^{1}$, okisetiono@gmail.com ${ }^{2}$
}

\begin{abstract}
Abstrak
Perkembangan teknologi router saat ini dapat menghubungkan jaringan antar komputer baik melalui jaringan kabel maupun nirkabel. Namun kekurangan dari router yang beredar saat ini belum dapat dikatakan optimal karena antara router satu dengan yang lain tidak memiliki keseragaman fasilitas, sehingga antara router satu dengan yang lain bisa memiliki fasilitas yang berbeda-beda dan tidak standar. Karena hal tersebut, maka perlu dibangun sistem baru yang memiliki fitur yang dapat mengoptimalkan fungsi router yang beredar dan dapat di terapkan pada router lain secara portable. Sistem baru ini dibangun dengan menggunakan sistem operasi openWRT. Sistem operasi openWRT akan dipasang pada sebuah router wireless dengan beberapa alat tambahan untuk mendukung fungsionalitasnya seperti flashdrive, modem gsm, usb soundcard dan speaker. Sistem yang dihasilkan memiliki fitur dan layanan yang sama antara router satu dengan yang lain, diantaranya dapat memberikan layanan captive portal, sistem juga mampu memberikan fasilitas chatting, audio dan video player. Selain itu, sistem ini juga memiliki beberapa fitur lain seperti penyimpanan lokal, mesin download dan voucher akses internet untuk login captive portal. Pada hasil pengujian, sistem dapat diterapkan pada perangkat lain dan digunakan secara portable.
\end{abstract}

Kata Kunci : router, hotspot, captive portal, openwrt, portable

\begin{abstract}
The current router technological developments can connect computers across the networks either through a wired or wireless network. But the shortcomings of currently available routers cannot said be optimum because each routers do not have the same facility. Therefore, it is necessary to build a new portable system that has features that can optimize the function of a router and can be applied to other routers. The new system is built using OpenWRT operating system. OpenWRT operating system will be installed on a wireless router with some additional tools to support functionality such as flash drive, gsm modem, usb soundcard and speakers. The resulting system create the same features and services on each routers, which it can provide a captive portal services, and also able to provide other facilities such as chat, audio and video player. In addition, this system also has several other features such as local storage, download machine and vouchers system for internet access using captive portal login. Test results shows that, the system can be applied to other devices and it is portable.
\end{abstract}

Keywords : router, hotspot, captive portal, openwrt, portable

\section{PENDAHULUAN}

Teknologi nirkabel menjadi sesuatu yang sangat populer di dunia karena perkembangan dan penggunaannya dalam jaringan komputer lokal (LAN). Yang dimaksudkan disini adalah WiFi. WiFi adalah sekumpulan standar yang digunakan untuk Jaringan Lokal Nirkabel (Wireless Local Area Networks / WLAN) berdasar pada spesifikasi IEEE 802.11 [1]. Sejak 
diperkenalkan kepada publik pada tahun 1997 hingga sekarang, WiFi mengalami kemajuan yang cukup pesat. Hingga saat ini telah ada 5 standard WiFi yang telah dirilis di pasar, diantaranya adalah $802.11 \mathrm{a}, \mathrm{b}, \mathrm{g}, \mathrm{n}$ dan ac. Standar ini diterbitkan oleh IEEE dan setiap standar yang dirilis merupakan pengembangan dari standar sebelumnya. Sejak produk awal dari WiFi yaitu $802.11 \mathrm{~b}$, pita frekuensi yang digunakan dalam pengoperasiannya adalah pada 2,4 GHz. Terkecuali pada 802.11 a, frekuensi yang digunakan adalah $5 \mathrm{GHz}$. Tujuan digunakannya pita frekuensi yang lebih tinggi ini disebabkan oleh fakta bahwa frekuensi 2,4 GHz semakin padat [1].

Setiap perangkat jaringan kabel dan nirkabel yang dijual di pasaran pasti memiliki sertifikasi WiFi. Tiap-tiap perangkat ini memiliki standar yang berbeda-beda tergantung kemampuannya, akan tetapi saat ini sebagian besar telah menggunakan standar $802.11 \mathrm{n}$, Khususnya router, Setiap perangkat router ini memiliki fitur yang digunakan untuk mendukung jaringan nirkabel seperti sistem keamanan jaringan dan kemampuan untuk berkomunikasi dengan perangkat lainnya. Namun router yang beredar di pasaran kemampuanya belum dapat dikatakan optimal [2]. Di karenakan keseragaman fasilitas yang berbeda-beda. Untuk itu perlu adanya penggantian firmware dari Original ke firmware OpenWRT yang support dengan tujuan memaksimalkan dari kemampun device router tersebut [3]. Selain itu tujuan dari penggunaan fitur ini umumnya adalah untuk mengubah firmware original menjadi firmware Open Source. Akan tetapi dalam penggunaan fitur ini diikuti dengan penggunaan modul pelengkap untuk membangun sistem hotspot portable yang dapat di terapkan dengan perangkat lain dengan mudah.

Jaringan komputer sangat berperan penting saat ini untuk memenuhi kebutuhan masyarakat. jaringan komputer terbukti dapat mempermudah user atau pemakainya untuk saling berkomunikasi serta memperoleh informasi yang dibutuhkan [1]. Pemakai bisa saling berkirim pesan atau bercakap-cakap secara langsung serta mengirim dan mengambil file. Dalam perkembangan teknologi perangkat-perangkat jaringan komputer dapat membantu menghubungkan dua perangkat atau lebih yang berfungsi untuk mengelola suatu jaringan dan dapat berkomunikasi antar jaringan. Salah satu perangkat jaringan komputer tersebut adalah router.

Router adalah sebuah perangkat yang akan melewatkan paket IP dari suatu jaringan ke jaringan yang lain [4]. Dalam perkembangan teknologi, router memliki 2 jenis yaitu: router dengan wireless dan router tanpa wireless. Router wireless bekerja dengan memancarkan gelombang radio pada frekuensi tertentu dan router tanpa wireless bekerja dengan menggunakan kabel RJ45 yang saling terhubung dengan komputer. Dengan berbagai fasilitas yang dimiliki router, seperti pengaturan routing, pengaturan gateway server, manajemen bandwith, file sharing, akses internet, permasalahan pada jaringan komputer akan bisa terjawab. Dalam perkembangan router, salah satu penelitian yang berjudul "Optimalisasi Router Linksys WRH54G Dengan DD-WRT" oleh [4] menyatakan router belum dapat bekerja dan memberikan fungsi secara optimal. Penelitian yang dilakukan yaitu dengan mengganti firmware / sistem operasi pada fasilitas upgrade firmware pada router. Hasil yang di berikan setelah mengganti sistem operasi pada router menggunakan DD-WRT yaitu adanya Wireless konfigurasi pilihan mode On, Virtual Interface, Daftar Mac Address Filtering yang bisa mencapai 256 klien. Dalam perkembangan teknologi router yang sudah ada, perlu adanya optimalisasi router.

Dalam penelitian ini akan dilakukan implementasi sistem hotspot portable dalam perangkat router TP-LINK MR-3420 yang dilakukan dengan bantuan openWRT, yang merupakan OS opensource untuk perangkat router dan sistem tersebut diterapkan pada perangkat lain yaitu huawei echo life HG553. Kekurangan dari OpenWRT adalah pada penambahan ekstra pada konsumsi daya listrik yang sebenarnya terbatas untuk router [5]. Namun tetap bisa di carikan jalan keluar dengan memamakai USB Hub yang tersedia arus DC / adaptor di dalamnya. Sehingga konsumsi daya nya tidak memberatkan kinerja router. Selain itu kekurangan yang lain adalah dari segi arsitektur router untuk penerapan pada perangkat lain . Hal inilah yang dianalisa dalam penelitian ini untuk mengetahui sejauh mana sistem hotspot portable berjalan dengan baik dan memberikan fasilitas penyimpanan lokal, audio player, video 
player dan chatting. Dalam melakukan analisa ini digunakan bantuan modul-modul perangkat lunak dan modul-modul perangkat keras. Hasil analisa ini diharapkan sistem hotspot portable dapat di terapkan pada perangkat lain.

\section{METODE PENELITIAN}

Rancang bangun sistem ini dibagi menjadi dua fokus kerja yaitu [6] :

- Pembuatan perangkat keras (hardware)

- Pembuatan perangkat lunak (software)

Metode Pengembangan sistem pada penelitian ini mengacu pada metode Rapid Aplication Development (RAD) [6][7], yaitu adalah sebuah proses perkembangan perangkat lunak sekuensial linier yang menekankan siklus perkembangan dalam waktu yang singkat (30 sampai 90 hari) dengan pendekatan konstruksi berbasis komponen [8].

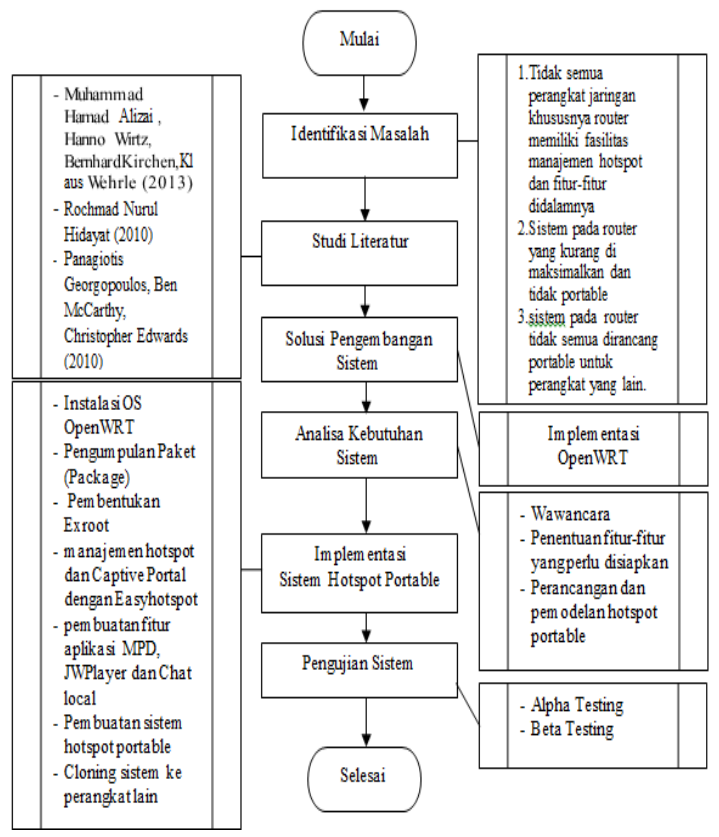

Gambar 1. Kerangka Penelitian

Sistem hotspot portable yang akan dibangun merupakan sebuah alternatif baru didalam optimalisasi router. Sistem ini dibangun secara embedded pada sebuah router dengan sistem operasi OpenWRT, dengan begitu maka sistem ini akan lebih kompatibel dan portable jika dibandingkan dengan sistem yang telah dibangun sebelumnya.

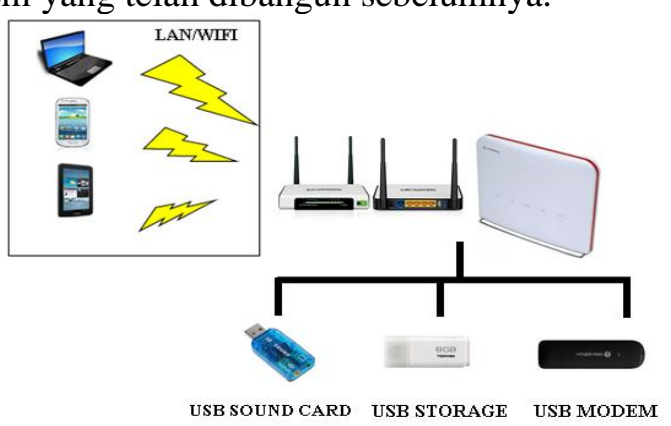

Gambar 2. Arsitektur Sistem Hotspot Portable 


\section{HASIL DAN PEMBAHASAN}

Pekerjaan utama dalam pembuatan perangkat lunak adalah melakukan instalasi openwrt pada perangkat router dan konfigurasi supaya mendukung untuk sistem keamanan jaringan menggunakan openWRT. Perangkat router yang digunakan dalam penelitian ini berjumlah dua buah dengan menggunakan router TP-LINK MR-3420 dan Huawei echo life HG553. Instalasi firmware yang dilakukan pada perangkat dilakukan dengan web interface dari firmware asli seperti yang dapat dilihat pada gambar berikut ini.

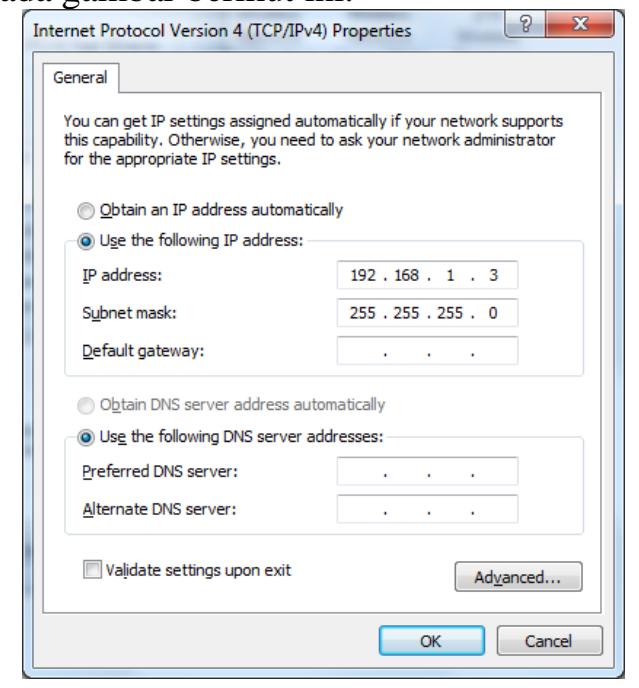

Gambar 3. Konfigurasi IP address pada klien

Router TP-LINK MR 3420 secara default memiliki IP gateway 192.168.1.1, maka agar bisa mengakses control panel router perlu konfigurasi IP address pada sisi klien. IP address yang dimasukkan kedalam klien harus satu network dengan IP address pada router seperti yang terlihat pada gambar 3. Setelah konfigurasi IP address selesai maka control panel dari router dapat diakses melalui browser pada alamat IP 192.168.1.1 seperti pada gambar 4.

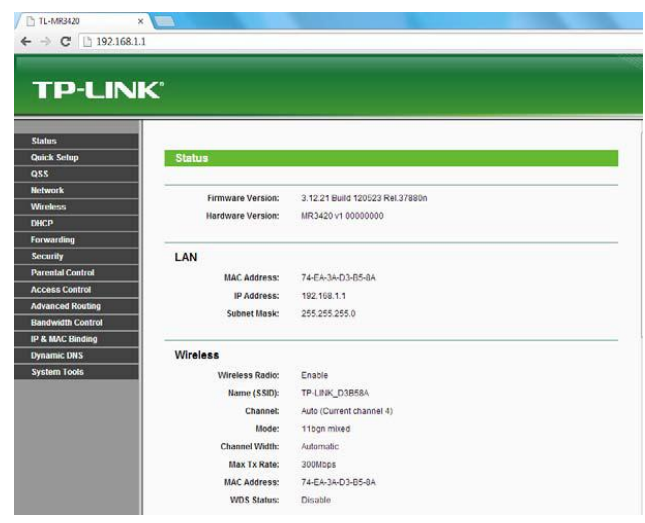

Gambar 4. Tampilan control panel default

Untuk mengganti firmware dengan openwrt, maka pilih menu System Tool kemudian Firmware Upgrade seperti pada gambar 5, Firmware OpenWRT sendiri dapat didownload melalui situs resmi www.openwrt.org. 


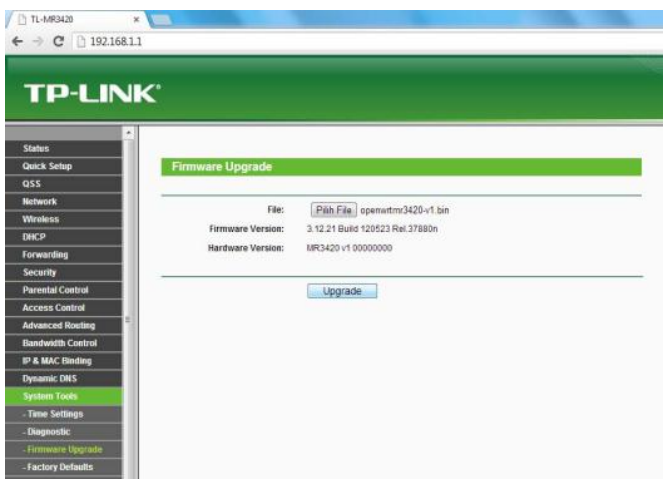

Gambar 5. Proses penggantian firmware menjadi OpenWRT

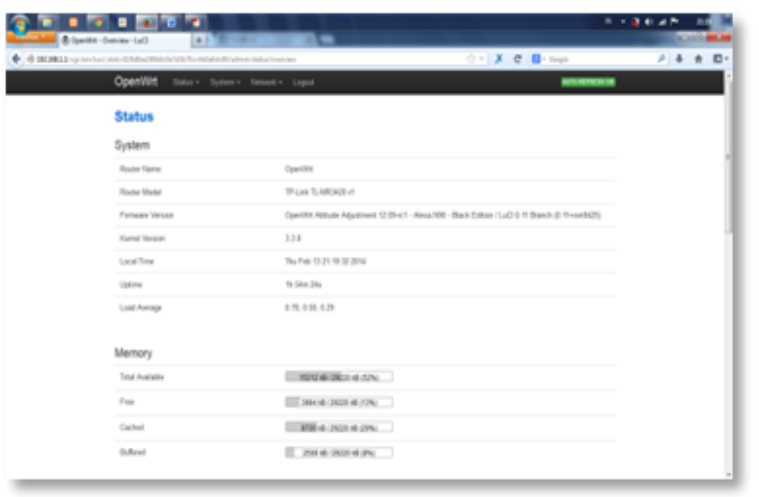

Gambar 6. Tampilan control panel OpenWRT

Setelah proses penggantian firmware selesai maka router dapat kembali diakses dengan memasukkan alamat ip 192.168.1.1 pada browser seperti pada gambar 6. Langkah selanjutnya adalah menyusun alat-alat yang digunakan sesuai dengan skema sistem hotspot portable. Pada penelitian ini sistem sistem hotspot portable menggunakan perangkat keras 2 buah flashdrive sebagai penyimpanan, USB Modem sebagai jalur koneksi internet, USB Souncard untuk merubah sinyal digital menjadi sinyal analog yang kemudian di teruskan ke sebuah speaker. Speaker ini digunakan sebagai penyalur suara untuk modul audio. Konfigurasi modul ini di jelaskan tiap-tiap metode yang digunakan baik dalam bentuk tampilan maupun sistem berjalan.

\subsection{Konfigurasi Modul}

Modul storage berfungsi menggunakan 2 flash drive berkapasitas 8GB. Flash drive ini berfungsi sebagai penambah kapasitas penyimpanan router yang terbatas dan pemberian fitur pada penyimpanan. Flash drive ini dipartisi menjadi 3 yaitu ext4, swap dan NTFS. Partisi ext4 digunakan untuk sistem operasi openWRT dan penyimpanan lokal untuk samba server yang kemudian diberikan captive portal beserta fitur chatting, audio dan video player, sedang partisi swap digunakan sebagai cadangan memori ketika memori internal router penuh.

Di dalam modul storage ini juga dikonfigurasi samba server. Samba server berfungsi untuk mempermudah pengguna dalam mengelola penyimpanan file yang dapat di download atau upload. Selain itu, file musik atau file video yang disimpan pada samba server di dalam router bisa didengarkan dan dilihat secara langsung melalui komputer ataupun smartphone pengguna tanpa harus melalui proses download. 


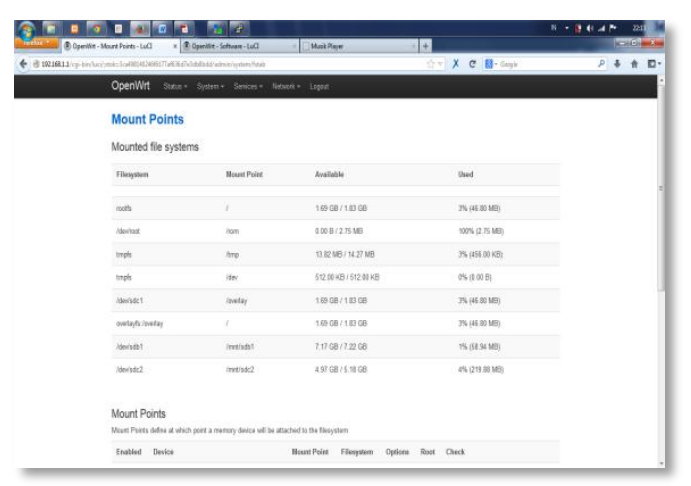

Gambar 7. Tampilan mount point penyimpanan OpenWRT

Pada modul storage ini, dapat digunakan sebagai media penyimpanan lokal menggunakan samba server. User yang sudah terhubung ke dalam sistem hotspot portable sudah dapat mengakses fasilitas samba server.

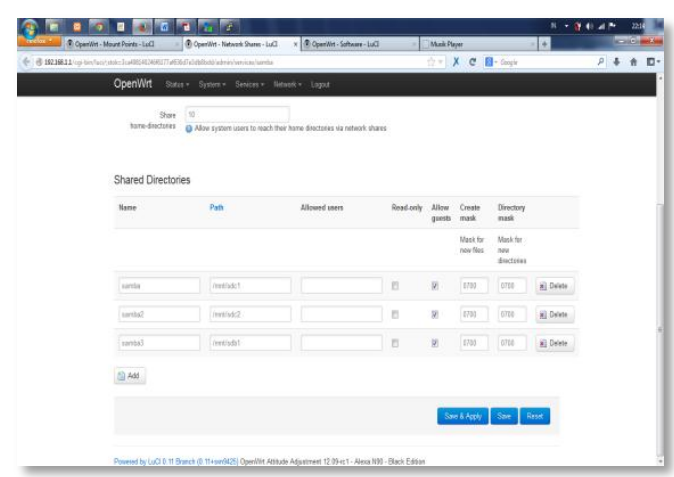

Gambar 8. Tampilan control panel samba server OpenWRT

Ketika admin sudah memberikan hak akses ke dalam samba server, maka user dapat menikmati fasilitas penyimpanan menggunakan mapping, seperti yang terlihat pada gambar 9 .

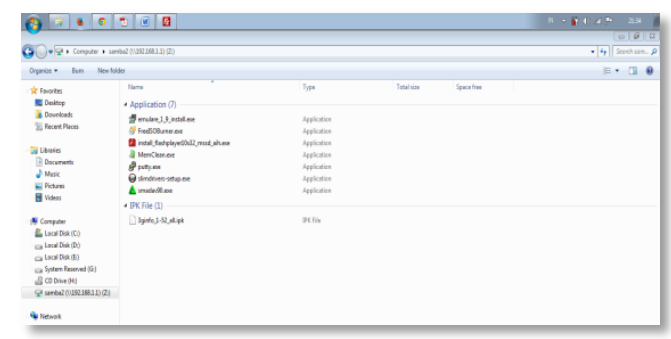

Gambar 9. Tampilan ketika user mengakses samba server

Selanjutnya setelah modul storage, lalu menambah modul mesin download, modul audio, modul video, modul chat dan modul easyhotspot. Modul tersebut adalah bagian dari sistem hotspot portable. Ketika user mengakses sistem hotspot portable maka user akan dialihkan kedalam halaman captive portal. 


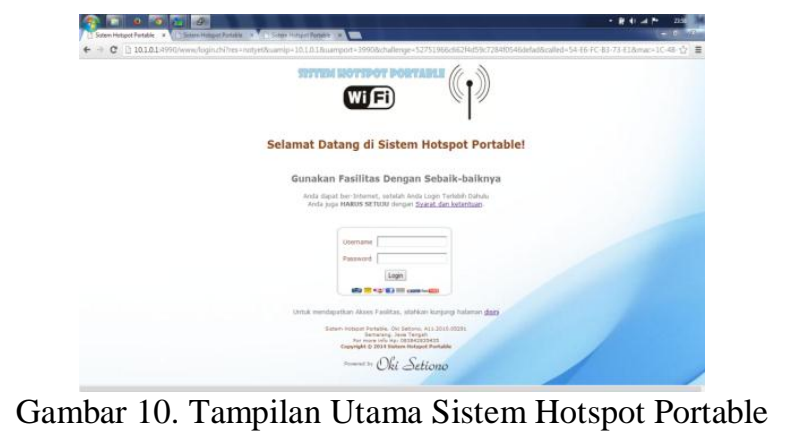

Halaman captive portal tersebut memberikan berbagai layanan dari akses user ke internet menggunakan modul easyhotspot untuk autentikasi login username dan password. User dapat melakukan request akses internet kepada admin berupa voucher yang di buat oleh admin.

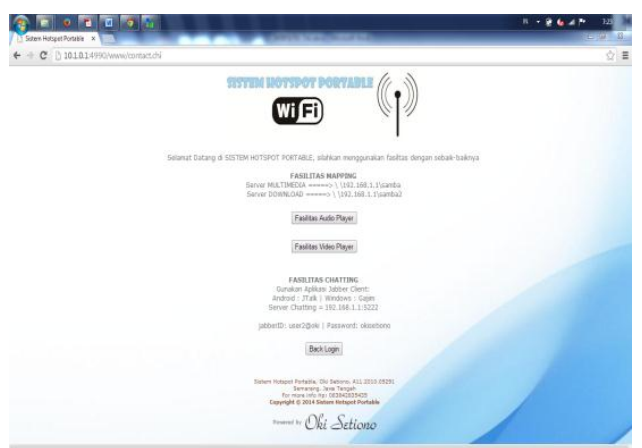

Gambar 11. Tampilan Fasilitas Sistem Hotspot Portable

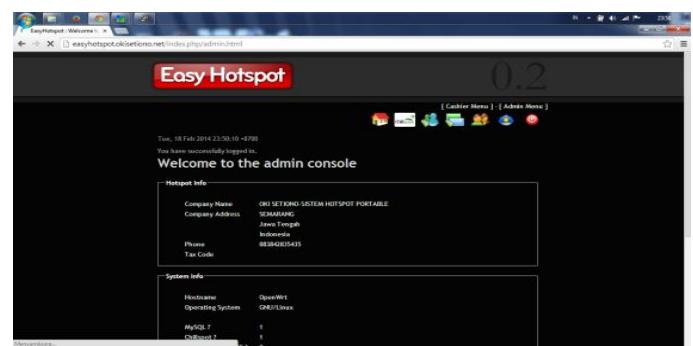

Gambar 12. Tampilan halaman admin easyhotspot

Modul easyhotspot ini menghubungkan antara database mysql dan coova yang di hubungkan oleh freeradius sehingga halaman captive portal dapat berjalan dengan baik. Akses dalam halaman captive portal untuk akses internet dikelola oleh easyhotspot berupa billing paket internet sehingga user yang akan melakukan akses internet mendapatkan akses internet username dan password berupa voucher seperti gambar 13.

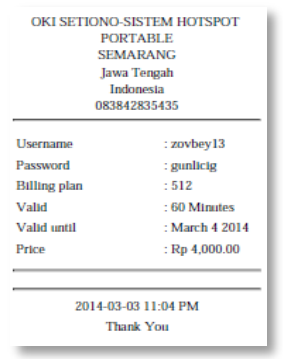

Gambar 13. Tampilan voucher akses internet 
Selain captive portal untuk akses internet, sistem hotspot portable memiliki fasilitasfasilitas pendukung, yaitu mesin donwload menggunakan aria2 dan transmission, fasilitas tersebut hanya memberikan link download yang berasal dari internet untuk di masukkan kedalam modul tersebut, sehingga link download tersebut akan di download di dalam router yang di simpan di dalam penyimpanan lokal.

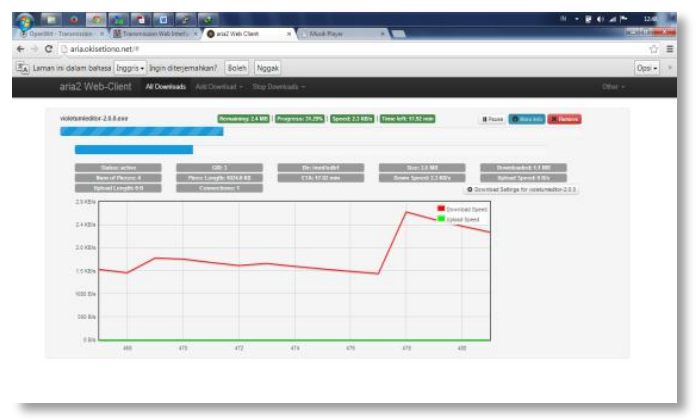

Gambar 14. Tampilan hasil proses mesin download aria2

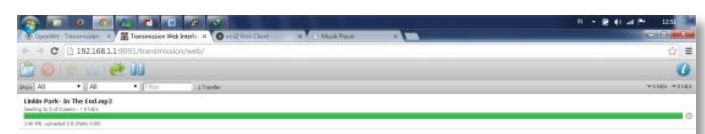

Gambar 15. Tampilan hasil proses mesin download transmission

Hasil dari link download tersebut dapat langsung di akses melalui fasilitas samba server. Fasilitas yang lainnya yaitu audio dan video player. Modul tersebut memberikan output fasilitas berupa suara dan gambar berupa streaming. Untuk audio yang digunakan menggunakan MPD (Music Player Daemon) dan video menggunakan JW Player yang berbasis opensource. Modul tersebut di masukkan kedalam sistem hotspot portable dan dapat di akses di dalam menu halaman captive portal sistem hotspot portable.

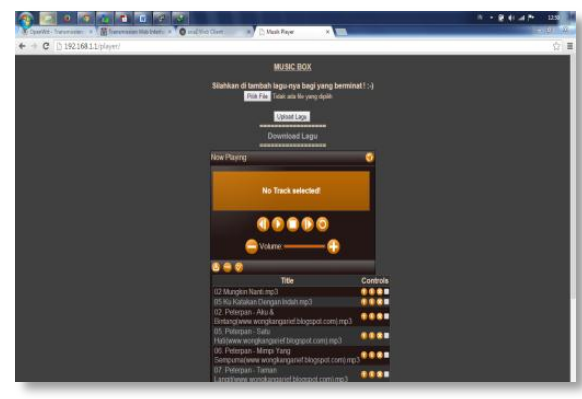

Gambar 16. Tampilan proses audio menggunakan MPD 


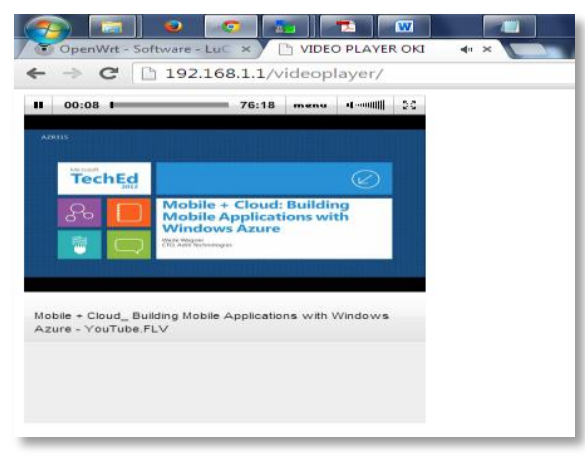

Gambar 17. Tampilan proses video menggunakan JW Player

Hasil proses dari audio dan video player dapat dilihat pada gambar 16 dan 17, keduanya dapat melakukan proses streaming baik audio dan video. Proses audio dan video player tersebut dapat diakses melalui halaman captive portal berupa link. Sehingga ketika link tersebut di akses maka user akan di alihkan ke dalam halaman audio atau video player tersebut.

Dalam sistem hotspot portable yang dibangun, terdapat fasilitas chating untuk komunikasi antar sesama user sehingga user yang terhubung dalam siste hotspot portable dapat menggunakan fasilitas chatting tersebut.

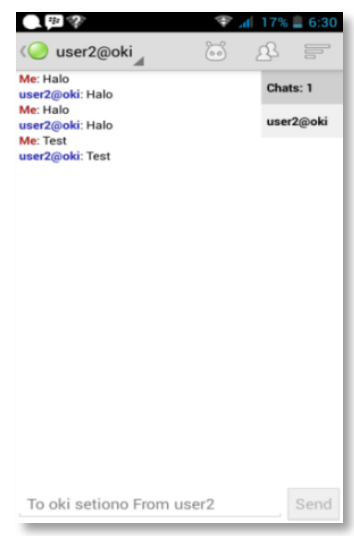

Gambar 18. Tampilan proses chatting

Fasilitas chatting yang digunakan diakses menggunakan smartphone dengan aplikasi JTALK. User yang terhubung dengan sistem hotspot portable dapat menggunakan fasilitas chatting dengan menggunakan akses usergroup berupa username dan password yang sudah di sediakan pada halaman captive portal.

Semua fasilitas dalam sistem hotspot portable dapat berfungsi dengan baik. Untuk memudahkan dalam akses baik melalui PC, Laptop, smartphone maupun tablet, modul virtual host LIGHTTPD diperlukan untuk berfungsi sebagai webserver untuk menampilkan layananlayanan berbasis web yang berbeda-beda dalam sebuah webserver.

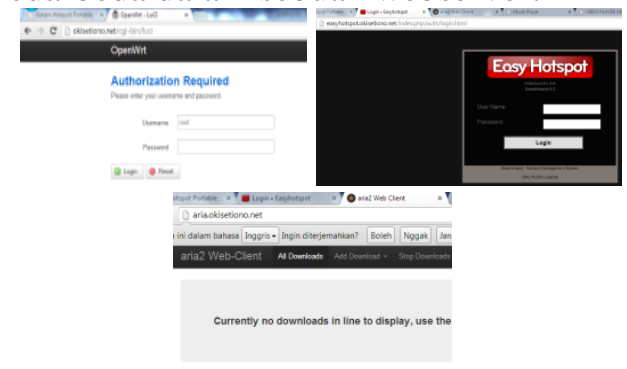

Gambar 19. Tampilan alamat virtual host dengan LIGHTTPD 


\subsection{Pengujian}

Pengujian terhadap sistem hotspot portable dilakukan untuk mengetahui sejauh mana sistem tersebut dapat diterapkan pada perangkat lain dan menguji kelayakan sistem yang dijalankan dengan membagikan kuisoner kepada responden.

Pengujian terhadap fungsionalitas sistem diterapkan pada perangkat router TP LINK 3420 dan Huawei Echolife HG553, hasil pengujiannya sebagai berikut :

Tabel 1. Tabel Pengujian Skenario

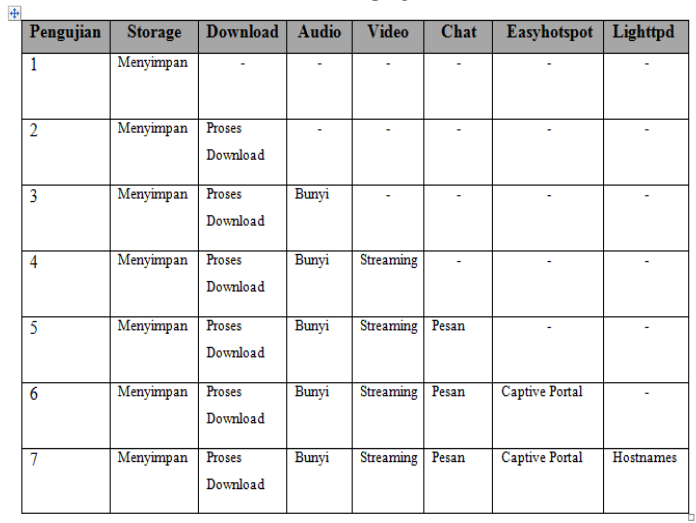

Proses pengujian skenario tersebut dilakukan secara 2 tahap yaitu pada skenario 1 pada router TP LINK 3420 dan skenario 2 pada router Huawei Echo Life HG553. Pengujian dilakukan dengan 7 pengujian, berdasarkan dari 7 pengujian pada tabel tersebut sistem hotspot portable dapat berjalan dengan baik pada kedua perangkat tersebut. 7 pengujian di lakukan di mulai dari pengujian penyimpanan, proses download, streaming audio, streaming video , mengirim pesan chating, akses halaman captive portal dan pengujian dengan alamat virtual.

Pada pengujian kuisoner dilakukan pengujian kelayakan sistem dengan latar belakang mahasiswa Teknik Informatika dan laboran UPT Laboratorium Komputer Fakultas Ilmu Komputer Universitas Dian Nuswantoro. Kuisoner difokuskan pada fungsionalitas dan tampilan antarmuka sistem.

Tabel 2. Tabel kuisoner fungsionalitas level 1

\begin{tabular}{|c|c|c|c|c|}
\hline No & Pernyataan & Level & $\mathbf{Y}$ & $\mathrm{T}$ \\
\hline 1 & Proses halaman admin router berjalan baik & 1 & 30 & 0 \\
\hline 2 & Proses menu fitur di dalam halaman admin berjalan baik & 1 & 29 & 1 \\
\hline 3 & Proses halaman captive portal bejalan baik & 1 & 26 & 4 \\
\hline 4 & Proses login dan logout captive portal berjalan baik & 1 & 28 & 2 \\
\hline 5 & Proses pembuatan Akun User easyhotspot bejalan baik & 1 & 29 & 1 \\
\hline 6 & Proses penyimpanan lokal berjalan dengan baik & 1 & 27 & 3 \\
\hline 7 & Proses audio MPD layer berjalan dengan baik & 1 & 25 & 5 \\
\hline 8 & Proses video JWPlayer bejalan dengan baik & 1 & 27 & 3 \\
\hline 9 & Proses chat local dapat berjalan dengan baik & 1 & 26 & 4 \\
\hline 10 & $\begin{array}{l}\text { Proses sinkronisasi penyimpanan dengan fitur berjalan } \\
\text { baik }\end{array}$ & 1 & 27 & 3 \\
\hline 11 & $\begin{array}{l}\text { Sistem hotspot portable dapat diakses melalui jaringan } \\
\text { lokal (LAN dan WIFI) }\end{array}$ & 1 & 27 & 3 \\
\hline 12 & $\begin{array}{l}\text { Fitur sistem hotspot portable dapat di akses melalui mobile } \\
\text { / smartphone dengan jaringan WIFI }\end{array}$ & 1 & 25 & 5 \\
\hline 13 & $\begin{array}{l}\text { Sistem ini sudah berfungsi layak sebagai sistem hotspot } \\
\text { portable }\end{array}$ & 1 & 27 & 3 \\
\hline \multicolumn{3}{|c|}{ Total } & 353 & 37 \\
\hline \multicolumn{3}{|c|}{ Persentase } & $91 \%$ & $9 \%$ \\
\hline
\end{tabular}


Tabel 3. Tabel kuisoner fungsionalitas level 2

\begin{tabular}{|c|c|c|c|c|}
\hline No & Pernyataan & Level & $\mathbf{Y}$ & $\mathrm{T}$ \\
\hline 1 & Proses halaman admin router berjalan baik & 2 & 30 & 0 \\
\hline 2 & Proses menu fitur di dalam halaman admin berjalan baik & 2 & 29 & 1 \\
\hline 3 & Proses halaman captive portal berjalan baik & 2 & 29 & 1 \\
\hline 4 & Proses login dan logout captive portal berjalan baik & 2 & 30 & 0 \\
\hline 5 & Proses pembuatan Akun User easyhotspot berjalan baik & 2 & 28 & 2 \\
\hline 6 & Proses penyimpanan lokal berjalan dengan baik & 2 & 27 & 3 \\
\hline 7 & Proses audio MPD layer berjalan dengan baik & 2 & 27 & 3 \\
\hline 8 & Proses video JWPlayer berjalan dengan baik & 2 & 26 & 4 \\
\hline 9 & Proses chat local dapat bejalan dengan baik & 2 & 24 & 6 \\
\hline 10 & $\begin{array}{l}\text { Proses sinkronisasi penyimpanan dengan fitur bejjalan } \\
\text { baik }\end{array}$ & 2 & 27 & 3 \\
\hline 11 & $\begin{array}{l}\text { Sistem hotspot portable dapat diakses melalui jaringan } \\
\text { lokal (LAN dan WIFI) }\end{array}$ & 2 & 28 & 2 \\
\hline 12 & $\begin{array}{l}\text { Fitur sistem hotspot portable dapat di akses melalui mobile } \\
\text { / smartphone dengan jaringan WIFI }\end{array}$ & 2 & 25 & 5 \\
\hline 13 & $\begin{array}{l}\text { Sistem ini sudah berfungsi layak sebagai sistem hotspot } \\
\text { portable }\end{array}$ & 2 & 27 & 3 \\
\hline \multicolumn{3}{|c|}{ Total } & 357 & 33 \\
\hline \multicolumn{3}{|c|}{ Persentase } & $92 \%$ & $8 \%$ \\
\hline
\end{tabular}

Tabel 4. Tabel kuisoner tampilan antarmuka

\begin{tabular}{|l|l|l|l|l|l|}
\hline No & \multicolumn{1}{|c|}{ Pertanyaan } & SS & \multicolumn{1}{|c|}{ S } & KS & TS \\
\hline 1 & Sistem memiliki navigasi yang mudah & 9 & 18 & 3 & 0 \\
\hline 2 & Tampilan sistem captive portal nyaman bagi pengguna & 5 & 22 & 3 & 0 \\
\hline 3 & Setiap menu berfungsi dengan baik & 10 & 18 & 2 & 0 \\
\hline 4 & Setiap fitur berfungsi dengan baik & 8 & 20 & 2 & 0 \\
\hline 5 & $\begin{array}{l}\text { Streaming audio dan video dapat didengarkan dan } \\
\text { ditonton dengan nyaman }\end{array}$ & 8 & 19 & 3 & 0 \\
\hline \multicolumn{2}{c|}{ Total } & 40 & 97 & 13 & 0 \\
\hline \multicolumn{2}{c|}{ Presentase } & $27 \%$ & $65 \%$ & $9 \%$ & $0 \%$ \\
\hline
\end{tabular}

Hasil pengujian sistem berdasarkan fungsionalitas sistem diperoleh kesimpulan bahwa sebagian besar responden menyatakan fungsionalitas sistem berfungsi dengan baik. Dari data hasil pengujian diketahui pada level 1 sebanyak $91 \%$ menyatakan fungsionalitas sistem berjalan dengan baik dan sisanya sebesar 9\% menyatakan sebaliknya. Kemudian pada level 2, sebanyak 92\% menyatakan fungsionalitas sistem berjalan dengan baik dan sisanya $8 \%$ menyatakan sebaliknya.

Hasil pengujian antarmuka sistem diperoleh kesimpulan bahwa sebagian besar responden setuju dengan sistem yang telah dibuat. Data hasil pengujian menunjukkan $27 \%$ sangat setuju, 65\% setuju, 9\% kurang setuju dan 0\% tidak setuju. Berdasarkan kedua pengujian diatas, dapat disimpulkan bahwa sistem hotspot portable ini layak digunakan sebagai alternatif untuk mengoptimalisasi router yang beredar di pasaran.

\section{KESIMPULAN}

Dari hasil yang didapatkan dalam implementasi dan pengetesan sitem yang telah dirancang dan di bangun, maka dapat diambil beberapa kesimpulan :

1. Sistem hotspot portable dengan menggunakan sistem operasi OpenWRT dapat dengan mudah diimplementasikan.

2. Sistem dapat memberikan kemudahan pengelolaan manajemen hotspot yang langsung siap digunakan ketika router digunakan.

3. Sistem mampu diterapkan pada perangkat lain dengan mudah. 
4. Hasil dari semua modul yang dijalankan dapat diakses langsung melalui komputer pengguna.

5. Sistem dapat diakses secara lokal melalui koneksi wire maupun wireless.

6. Memberikan alternatif optimalisasi router sistem hotspot manajemen dan fitur-fiturnya yang lengkap, hemat, praktis dan efisien.

\section{UCAPAN TERIMA KASIH}

Penulis mengucapkan terima kasih kepada seluruh pihak yang telah memberi dukungan baik moril maupun materiil terhadap penelitian ini.

\section{DAFTAR PUSTAKA}

[1] Wagito, 2007. Jaringan Komputer, Teori dan Implementasi Berbasis Linux. Yogyakarta: Gaya Media.

[2] Rochmad Nurul Hidayat. 2010. Implementasi Tomato Firmware Pada Linksys Wireless Router Dengan Proses Authentification, Authorization, Accounting Menggunakan Radius Server. Seminar Nasional Aplikasi Teknologi Informasi 2010 (SNATI 2010., pp.1-5.

[3] Alimuddin Yasin, 2013. Analisis, Perancangan Dan Pengamanan Jaringan Nirkabel Berbasis Captive Portal Menggunakan OpenWRT Pada Wireless Router TL-MR3420. Skripsi, AMIKOM, Yogyakarta, Mei 2013.

[4] Fitri Ismurhayanti. 2011. Optimalisasi Router Linksys WRH54G Dengan DD-WRT," Skripsi, STIMIK AMIKOM, Yogyakarta, Maret 2011.

[5] Yun-yu Lee, Ing-Yi Chen, Sy-Yen Kuo, Hsi-Hai Liu, and Yuh-Rong Leu. 2008. Implementation of OpenWRT-based IP PnP Gateway. ACM, no. 1, pp. 1-5, September 2008.

[6] Roger Pressman, 2005. Software Engineering: A Practitioner's Approach. New York: McGraw-Hill.

[7] LPK Wahana, 2005. Pengembangan Aplikasi Sistem Informasi Akademika Berbasis SMS dengan JAVA. Jakarta: Salemba.

[8] Septian Fajar Nugraha, 2010. Rancang Bangun Aplikasi Chat Conference Pada Mobile Phone Dengan Menggunakan Enkripsi. UIN, p. 68, Desember 2010. 